\title{
STUDENTS VIEWS ON THE ISSUES OF LOCKDOWN AND DEGREE OF CONCERN IN THE CONTEXT OF THE COVID-19 PANDEMIC
}

\author{
Vasileios Papavasileiou ${ }^{1^{\star}}$, Yota Xanthacou ${ }^{2}$, Eleni Nikolaou ${ }^{3}$, Agapitos Xanthis $^{4}$, \\ Nikos Andreadakis ${ }^{5}$, Maria Kaila ${ }^{6}$ \\ ${ }^{1}$ Assoc. Prof. Dr., University of the Aegean, Greece, vpapavasileiou@rhodes.aegean.gr \\ ${ }^{2}$ Prof. Em. Dr., University of the Aegean, Greece, xanthakou@rhodes.aegean.gr \\ ${ }^{3}$ Assist. Prof. Dr., University of the Aegean, Greece, enikolaou@rhodes.aegean.gr \\ ${ }^{4}$ Post-doc Researcher, University of the Aegean, Greece, a.xanthis@rhodes.aegean.gr \\ ${ }^{5}$ Prof. Dr., University of the Aegean, Greece, nandread@rhodes.aegean.gr \\ ${ }^{6}$ Prof.Em. Dr., University of the Aegean, Greece, kaila@rhodes.aegean.gr \\ ${ }^{*}$ Corresponding Author
}

\begin{abstract}
The present study, which is part of a broader research, explores students' views on lockdown issues and their degree of concern during the COVID-19 pandemic. An electronic questionnaire was used for the implementation of the research as a means of data collection, due to the period of the research in the midst of a pandemic. The research was conducted in Greece, in Rhodes, during the period between January and March, 2021. The reference population of the research was the approximately 200 first year students of the Department of Preschool Education and Educational Planning of the University of the Aegean in Greece. 142 female students of them completed the questionnaire.

The results of the research indicate differences in the views of students between those who exhibit a high degree of concern about Covid -19 and those with a low degree of concern. Regarding the way they are informed, it seems that internet, television, family and friends are preferred by both groups. Students with a low level of concern about Covid-19 seem to be more indifferent than students with a high level of concern who seem to be more afraid, to comply more with the suggested precautions and state that they have "unfolded" some talent during the lockdown period. In general, they are supported by family and their circle of friends, they demonstrate some empathy, they seek security by challenging the general climate of ideology or government services that are malfunctioning. Obviously, the issue of Covid-19, lockdown and digital communication is worth exploring further in relation to the Greek data and the new generation.
\end{abstract}

Keywords: Covid-19, lockdown, students, degree of concern

\section{LITERATURE REVIEW}

For first-year university students, the experience of the recent pandemic is paradoxically unusual. They invested years of effort in the coveted university admission, although distance learning and social distancing, impose changes in the education, social life and communication they dreamed of

The emergence of the Covid-19 pandemic caused great and profound upheavals in the life of all mankind: economic recession, telework, cessation of live communication-cooperation-participation. It is obvious that this is something "more than a virus" (Akbulut et al., 2020). It is a reversal, it imposes new regularities, it requires flexible problem-solving and management skills, an active and responsible collective culture, a 
rational approach and creative planning.

But do the young citizens have the right skills to manage the changes emerging from the Covid-19 pandemic? Do they have the skills to recognize that there is a problem, to put into action their personal responsibility and to do something about it, to look for material and emotional help from individuals and groups? Not to idle and try to "turn" problems into opportunities by utilizing lockdown time. We know that the typical school functions are associated mostly with the vocalization of "being", with the certainty "I know this" and "this I will do ". Skills that invest in the "what could be", "what I do not know" and reasoning are not cultivated. In addition, a stable and enduring "present" is a fiction. However, from a developmental perspective, phenomena never "are" but always "become" (Josephs \& Valsiner, 2007). Sometimes they "happen" suddenly and unexpectedly.

Over time, in the "reproductive" school environment the child stops observing, assuming, asking, researching, being curious and inventive. The center of gravity of the whole educational process shifts from the child to the adult, from the student to the teacher, to the parent, to the one they know, to whom they largely expect to be taught. Thus, over time, a "passive information system" is formed in which much of the detective activity and the understanding of experience derives from and is delivered to the student by an external organizer (Xanthacou, 2011; Xanthacou \& Kaila, 2011; Xanthacou et al., 2018). The tendency of citizens to expect problem-solving - especially creative problem-solving - from the family, the director, the principal, the "boss"... the aliens is gradually developing!

Covid-19 highlighted the need to make learning more flexible. Even before Covid-19, the Agenda for Education 2030 and Sustainable Development Goal 4 recognized the need for flexible universities that would provide different learning paths while supporting equity and lifelong learning. International research has shown that by combining face to face learning with distance learning, education works better and for more students that may work or have other commitments (Martin \& Furiv, 2020).

But what happens when trying to solve problems, such as through online Education, some others emerge? That is, the emergence of inequalities due to socio-economic problems (families with many children in school age), the unpleasant experience of isolation, the lack of interaction and live exchange, the physical immobility from prolonged time spent on online classes and finally emotional problems and frustration from deprivation of student life (Dhawan, 2020; Saladino, et al., 2020; Alghamdi, 2021; Chaturvedi et al., 2021).

As a subject in iconic society (Tasis, 2017), the online student is invisible to his / her fellow students and his/her professors. He/she records information, completes tasks, tries to be correct and consistent. He/she is organized rationally, but how much does he/she adapt creatively to new requirements and goals? To what extent can students participate in spiritual fermentations, exchanges, fruitful discussions or disagreements, explorations and experiences in physical reality that act as excellent conduits of creative learning?

\section{METHODOLOGY}

The purpose of this research is to study the relation of the degree of concern of students about covid-19 with a) the media / persons by whom they obtain information about the pandemic, with the extent that they follow the measures proposed by health services and $b$ ) the degree of their trust in institutions, services and individuals when facing a problem. More specifically, based on the degree of students' concern about Covid19, the following are explored:

- Situations that trigger a low or high level of concern in students about covid-19,

- The media or persons from whom they obtain their information and knowledge about covid-19.

- To what extent do they comply with the measures proposed by the health services.

- To what extent did they utilize the lockdown time and "unfold" some of their talent.

- The verbs that characterize their situation during the Lockdown period.

- The persons or bodies that they consider supportive when facing a problem.

- The factors that they consider as inhibiting.

The research was conducted in the midst of a pandemic while the students were participating in the courses exclusively online, by digital and not live presence. It was decided to be used an electronic questionnaire as a means of data collection. The conversion of the questionnaire from printed to electronic form was achieved through the open application Google Forms.

The reference population of the research was approximately 200 first-year students of the Department of 
Sciences of Preschool Education and Educational Planning of the University of the Aegean. Students were given 15 days to respond to the questionnaire. At the completion of the questionnaire, 142 students finally responded. Students potentially come from any part of the country.

The research variables, depending on their scale of measurement, i.e the type of values they receive, were classified into the basic categories of categorical and qualitative variables. The group of qualitative variables included those for which the five-point Likert scale was used. The Likert scale used in this questionnaire was: $1=$ Not at all, $2=$ Slightly, $3=$ Moderately, $4=$ Enough concerned and $5=$ Very much concerned.

Students were divided into two groups in total, taking into account the answers given to the relevant question: "How much worried are you about the covid-19 epidemic in our country?" due to the relatively small sample size as well as for reasons of validity and reliability of the inductive statistical analyzes, with the aim of analyzing the research data concerning the degree of concern of the students of the sample for the covid19 epidemic.

Students who answered "not at all", "slightly" or "moderately" were the first group of those who expressed a low degree of concern (44 or $39.0 \%$ ), while students who chose the categories "enough concerned" or "Very much concerned" were the second group of those who express a high degree of concern (98 or $69.0 \%$ ). Thus, the initial qualitative variable "degree of concern about the covid-19 epidemic" was transformed into a two-fold category with values "low" and "high" degree of concern.

At the level of inductive statistics, in order to explore the relation between the two-fold categorical variable "degree of concern about the covid-19 epidemic" and: a) another categorical variable, the Pearson chiSquare statistical criterion was applied, b) any qualitative variable, the statistical criterion IndependentSamples T Test was applied. If the variance homogeneity test of the qualitative variable (performed with Levene's test) showed inhomogeneity of the standard deviations, then we used an adjusted t-test value for unequal variances. Finally, in all cases of statistical control, $p=.05$ was adopted as the minimum level of statistical significance.

\section{RESULTS BASED ON THE DEGREE OF CONCERN OF STUDENTS ABOUT COVID-} 19

Table 1 shows the distribution of sample students' responses to their views on the type of concern about covid-19, based on their degree of concern about it. The same table presents the results from the statistical significance test of differences.

\section{Table 1:}

Distribution of students' responses regarding their concern about covid-19, based on their degree of concern about it. Statistical significance control of the differences

\begin{tabular}{|c|c|c|c|c|}
\hline \multirow{3}{*}{ Concern about Covid-19 } & \multicolumn{2}{|c|}{ Degree of concern covid-19 } & \multirow{2}{*}{\multicolumn{2}{|c|}{$\begin{array}{c}\text { Statistical } \\
\text { Significance Test }\end{array}$}} \\
\hline & \multirow{2}{*}{$\begin{array}{l}\text { Low } \\
(\%)\end{array}$} & \multirow{2}{*}{$\begin{array}{l}\text { High } \\
(\%)\end{array}$} & & \\
\hline & & & $x^{2}$ & $p$ \\
\hline $\begin{array}{l}\text { I am worried because there are elderly and vulnerable } \\
\text { people in our home }\end{array}$ & 18,2 & 16,3 & & \\
\hline $\begin{array}{l}\text { I am not worried, because I do not think that it is such } \\
\text { a big problem as the media presents it, nor that cases } \\
\text { have increased among young people }\end{array}$ & 40,9 & 4,1 & & \\
\hline $\begin{array}{l}\text { I am not worried, I am not naive to believe that there } \\
\text { is covid- } 19 \text {, we are not sheep }\end{array}$ & 0,0 & 0,0 & & \\
\hline $\begin{array}{l}\text { I am worried, because with covid-19 there is also an } \\
\text { economic crisis and an increase in unemployment }\end{array}$ & 9,1 & 26,5 & 41,673 & .000 \\
\hline $\begin{array}{l}\text { I am not worried. We are not stressed because we are } \\
\text { young people, because even if we catch it, we will get } \\
\text { through it lightly. You can't go out. }\end{array}$ & 4,5 & 0,0 & & \\
\hline $\begin{array}{l}\text { I am worried, because the virus is new and the } \\
\text { complications it creates are almost unknown. I avoid } \\
\text { closed spaces, I wear a mask. }\end{array}$ & 13,6 & 38,8 & & \\
\hline Other & 13,6 & 14,3 & & \\
\hline
\end{tabular}

The statistical significance test of Table 1 shows that there is a statistically significant difference in the views of students who have a high degree of concern about covid-19 compared to those who have a low level of concern regarding the reasons for concern or not $(p=.000)$. 
The data of the table show that the difference is mainly due to the fact that students who have a high degree of concern note to a higher degree the reasons "I am worried, because the virus is new and the complications it creates are almost unknown. I avoid indoor spaces, I wear a mask" "(38.8\% vs. $13.6 \%)$ and "I am worried, because simultaneously with covid-19 there is also an economic crisis and an increase in unemployment "(26.5\% vs. $9.1 \%)$. In contrast, students with a low level of concern cite at a much higher rate the reason "I do not worry, because I do not think it is such a big problem as the media presents it, nor the incidence among young people has increased" (40.9\% versus $4.5 \%)$.

Table 2 shows the means and standard deviations of students' responses for each of the media / persons who provide us with information about covid-19, based on their degree of concern about it. The same table explores the statistical significance of the differences of the means.

\section{Table 2:}

Mean and standard deviations of students' responses to each of the media / person by whom they were informed about covid-19, based on their degree of concern about it. Statistical significance test of the mean differences

\begin{tabular}{|l|c|c|c|c|c|c|}
\hline \multirow{2}{*}{ Media/Persons who provide with information } & \multicolumn{3}{c|}{ Degree of concern about } & \multicolumn{2}{c|}{$\begin{array}{c}\text { Statistical } \\
\text { COVID-19 }\end{array}$} & \multicolumn{3}{c|}{ Significance Test } \\
\cline { 2 - 7 } & \multicolumn{2}{|c|}{ Low } & \multicolumn{2}{c|}{ High } & \multicolumn{1}{c|}{} \\
\cline { 2 - 7 } & $\mathbf{M}$ & SD & $\mathbf{M}$ & SD & $\mathbf{t}$ & $\mathbf{p}$ \\
\hline Pharmacists & 1,50 & 0,67 & 1,67 & 1,12 & $-1,148^{*}$ & .253 \\
\hline Television & $\mathbf{3 , 0 9}$ & $\mathbf{1 , 4 6}$ & $\mathbf{3 , 6 7}$ & $\mathbf{1 , 0 8}$ & $\mathbf{- 2 , 3 7 1 ^ { * }}$ & $\mathbf{. 0 2 1}$ \\
\hline Internet & $\mathbf{2 , 9 5}$ & $\mathbf{1 , 4 1}$ & $\mathbf{3 , 8 8}$ & $\mathbf{1 , 1 1}$ & $\mathbf{- 3 , 8 3 7 ^ { * }}$ & $\mathbf{. 0 0 0}$ \\
\hline Friends & $\mathbf{2 , 1 4}$ & $\mathbf{1 , 0 3}$ & $\mathbf{2 , 6 7}$ & $\mathbf{1 , 0 4}$ & $\mathbf{- 2 , 8 5 2}$ &. $\mathbf{0 0 5}$ \\
\hline Newspapers - magazines & 1,45 & 0,90 & 1,73 & 1,25 & $-1,512^{*}$ & .133 \\
\hline Doctors & 2,50 & 1,32 & 2,69 & 1,36 & $-0,790$ & .431 \\
\hline Family & $\mathbf{2 , 6 4}$ & $\mathbf{1 , 2 4}$ & $\mathbf{3 , 5 9}$ & $\mathbf{1 , 2 2}$ & $\mathbf{- 4 , 3 0 0}$ &. $\mathbf{0 0 0}$ \\
\hline
\end{tabular}

*The corrected value $t$ was applied, due to the inequality of variances

The data of Table 2 indicate the following findings: a) For three (3) of the seven (7) media / persons no statistically significant differences were found between the mean scores of the two groups. These are the pharmacists, newspapers - magazines and their personal doctor. b) Statistically significant differences between those with a low degree of concern and those with a high degree of concern about covid-19 were identified in the remaining four cases of media and persons.

In fact, in all cases the mean of the group with a high degree of concern was found to be significantly higher than the corresponding mean of the group with a low degree of concern. More specifically: i) regarding television $(p=.021)$, the mean of the group with a high degree of concern was 3.67 compared to 3.09 of the group with a low degree of concern, ii) regarding the internet $(p=.000$, mean $=3.88$ vs. mean $=2.95)$, iii) regarding friends $(p=.005$, mean $=2.67$ vs. mean $=2.14)$, and iv) regarding family $(p=.000$, mean $=3.59$ vs. mean $=2.64$ ).

Table 3 shows the means and standard deviations of students' responses to each of the problems that hinder the achievement of their goals and complicate their daily effort, based on their degree of concern about covid-19. The same table explores the statistical significance of the differences between the means.

\section{Table 3}

Means and standard deviations of students' responses to each of the problems that hinder the achievement of their goals and complicate their daily effort, based on their degree of concern about it. Statistical significance test of the differences between the means

\begin{tabular}{|l|c|c|c|c|c|c|}
\hline \multirow{2}{*}{ Problems } & \multicolumn{3}{c|}{$\begin{array}{c}\text { Degree of concern about } \\
\text { covid-19 }\end{array}$} & \multicolumn{2}{c|}{$\begin{array}{c}\text { Statistical } \\
\text { Significance Test }\end{array}$} \\
\cline { 2 - 7 } & \multicolumn{3}{|c|}{ Low } & \multicolumn{2}{c|}{ High } & \\
\cline { 2 - 7 } & $\mathbf{M}$ & SD & $\mathbf{M}$ & SD & $\mathbf{t}$ & $\mathbf{p}$ \\
\hline Corruption within the country & 3,09 & 1,18 & 3,35 & 1,24 & $-1,152$ & .251 \\
\hline Dysfunctional services & $\mathbf{3 , 7 7}$ & $\mathbf{0 , 9 1}$ & $\mathbf{3 , 3 1}$ & $\mathbf{1 , 0 0}$ & $\mathbf{2 , 6 4 3}$ &. $\mathbf{0 0 9}$ \\
\hline Ideological decline & 3,55 & 1,21 & 3,22 & 1,21 & 1,465 & .145 \\
\hline
\end{tabular}


IJAEDU- International E-Journal of Advances in Education, Vol. VII, Issue 21, December, 2021

\begin{tabular}{|l|c|c|c|c|c|c|}
\hline Lack of prevention and decline & 3,68 & 1,24 & 3,43 & 1,15 & 1,187 & .237 \\
\hline Increasing automatization & 3,14 & 1,15 & 2,82 & 1,25 & 1,447 & .150 \\
\hline Deficits in the education system & 3,68 & 1,03 & 3,78 & 1,14 & $-0,468$ & .641 \\
\hline
\end{tabular}

The data in Table 3 show the following findings: a) For five (5) of the six (6) problems, no statistically significant differences were found in the mean values of the two groups. b) There was a statistically significant difference between those with a low degree of concern and those with a high degree of concern about covid-19 only in the variable of the "Dysfunctional Services" problem $(p=.009)$. The mean of the group with a low degree of concern was found to be significantly higher than the mean of the group with a high degree of concern (3.77 vs. 3.31).

Table 4 shows the means and standard deviations of the students' answers for the degree to which they comply with the measures proposed by the health services, based on their degree of concern about covid19. The same table shows the statistical significance test of the differences between the means.

\section{Table 4:}

Mean and standard deviations of students' responses for the degree to which they comply with the measures proposed by the health services, based on their degree of concern about covid-19. Statistical significance test of the mean differences

\begin{tabular}{|c|c|c|c|c|c|c|}
\hline \multirow{3}{*}{ Suggested Measures } & \multicolumn{4}{|c|}{$\begin{array}{l}\text { Degree of concern about } \\
\text { COVID-19 }\end{array}$} & \multirow{2}{*}{\multicolumn{2}{|c|}{$\begin{array}{c}\text { Statistical } \\
\text { Significance Test }\end{array}$}} \\
\hline & \multicolumn{2}{|c|}{ Low } & \multicolumn{2}{|c|}{ High } & & \\
\hline & $\mathbf{M}$ & SD & $\mathbf{M}$ & SD & $\mathbf{t}$ & $\mathbf{p}$ \\
\hline $\begin{array}{l}\text { The degree to which health services comply } \\
\text { with the suggested measures }\end{array}$ & 3,32 & 0,98 & 4,39 & 0,70 & $-6,518^{*}$ & .000 \\
\hline
\end{tabular}

* The corrected value of $t$ was applied, due to the inequality of variances.

The data in Table 4 show that there is a statistically significant difference in the means of the responses of the students concerning the degree to which they comply with the measures proposed by the health services, based on their degree of concern about covid-19 $(p=.000)$. The mean of students' responses with a high degree concern about covid-19 is significantly higher than the recommended measures compared to their students with a low degree of concern (4.39 vs. 3.32).

Table 5 describes the distribution of students' responses to whether they "unfolded" any of their talent during the lockdown period, based on their degree of concern about covid-19. The same table presents also the statistical significance test of the differences in the values between the two groups.

\section{Table 5}

Distribution of students' responses to whether they "unfolded" any of their talents during the lockdown period, based on their degree of concern about covid-19. Statistical significance test of mean differences

\begin{tabular}{|c|c|c|c|c|c|c|}
\hline \multirow{3}{*}{ «Unfolding a talent» } & \multicolumn{4}{|c|}{$\begin{array}{c}\text { Degree of concern about } \\
\text { COVID-19 }\end{array}$} & \multirow{2}{*}{\multicolumn{2}{|c|}{$\begin{array}{c}\text { Statistical } \\
\text { Significance } \\
\text { Test }\end{array}$}} \\
\hline & \multicolumn{2}{|c|}{ Low } & \multicolumn{2}{|c|}{ High } & & \\
\hline & $\begin{array}{l}\text { Yes } \\
(\%)\end{array}$ & $\begin{array}{l}\text { No } \\
(\%)\end{array}$ & $\begin{array}{l}\text { Yes } \\
(\%)\end{array}$ & $\begin{array}{l}\text { No } \\
(\%)\end{array}$ & $x^{2}$ & $\mathbf{p}$ \\
\hline «Unfolding a talent» during lockdown & 40,9 & 59,1 & 59,2 & 40,8 & 4,077 & .043 \\
\hline
\end{tabular}

According to the statistics of table 5 it appears that there is -even marginally-statistically significant difference between the two groups $(p=.043)$. According to the descriptive data of the table it can be seen that those students who expressed a high degree of concern about covid-19 claim to a significantly higher percentage that they "unfolded" some talent during the quarantine period compared to their colleagues with a low degree of concern (59, $2 \%$ vs. $40.9 \%)$.

Table 6 lists the means and standard deviations of students' answers for each of the verbs that characterize them during the lockdown period, based on their degree of concern about covid-19. The same table presents the statistical significance of the mean differences.

The data in Table 6 show the following: a) from nine (9) of the seventeen (17) verbs that characterize them, no statistically significant differences ( $p>$.05) were found in the mean values of the two groups. These are the verbs: I swear, I communicate, I relax, I get bored, I work, I get irritated, I cook, I clean and I shop. 


\section{Table 6}

Mean and standard deviations of students' answers for each of the verbs that characterize them during the lockdown period, based on their degree of concern about covid-19. Statistical significance test of the mean differences

\begin{tabular}{|c|c|c|c|c|c|c|}
\hline \multirow{3}{*}{ VERBS } & \multicolumn{4}{|c|}{$\begin{array}{c}\text { Degree of concern about } \\
\text { COVID-19 }\end{array}$} & \multirow{2}{*}{\multicolumn{2}{|c|}{ Statistical }} \\
\hline & \multicolumn{2}{|c|}{ Low } & \multicolumn{2}{|c|}{ Mean } & & \\
\hline & $\mathbf{M}$ & SD & $\mathbf{M}$ & SD & $t$ & $p$ \\
\hline I am afraid & 1,95 & 1,03 & 3,14 & 1,00 & $-6,504$ & .000 \\
\hline I am careful & 3,41 & 1,00 & 4,39 & 0,64 & $-5,993^{\star}$ & .000 \\
\hline I swear & 2,50 & 1,32 & 2,14 & 1,18 & 1,603 & .111 \\
\hline I am worried & 2,68 & 1,03 & 3,94 & 0,77 & $-7,241$ & .000 \\
\hline I communicate & 3,77 & 1,01 & 3,96 & 0,91 & $-1,094$ & .276 \\
\hline I relax & 3,18 & 1,32 & 3,35 & 1,03 & $-0,810$ & .419 \\
\hline I search & 2,73 & 1,07 & 3,33 & 1,21 & $-2,833$ & .005 \\
\hline I do not care & 2,41 & 1,25 & 1,63 & 0,97 & $3,670^{*}$ & .000 \\
\hline I get bored & 3,18 & 1,66 & 3,37 & 1,36 & $-0,650$ & .518 \\
\hline I groom myself & 2,27 & 1,15 & 2,88 & 1,09 & $-3,013$ & .003 \\
\hline I work & 2,36 & 1,60 & 2,53 & 1,42 & $-0,622$ & .535 \\
\hline I get irritated & 3,00 & 1,46 & 3,10 & 1,40 & $-0,397$ & .692 \\
\hline I cook & 2,82 & 1,42 & 3,14 & 1,32 & $-1,327$ & .187 \\
\hline I clean & 3,05 & 1,24 & 3,45 & 1,17 & $-1,869$ & .064 \\
\hline I eat & 3,18 & 0,90 & 3,71 & 1,00 & $-3,039$ & .003 \\
\hline I shop & 2,23 & 0,96 & 2,43 & 1,02 & $-1,110$ & .269 \\
\hline I read & 3,36 & 1,12 & 4,04 & 1,12 & $-3,623$ & .001 \\
\hline
\end{tabular}

* The corrected value of $t$ was applied, due to the inequality of variances.

b) For one and only verb from the remaining eight (8), a statistically significant difference was found between the two groups, with the mean being significantly higher for the group of students with a low degree of concern about covid-19. This is the verb "I do not care" $(p=.000)$, with a mean of 2.41 for the group with a low degree of concern, compared to 1.63 for the group with a high degree of concern.

c) In all the other seven (7) verbs, the means were found to be significantly higher in the high concern group compared to the low concern group. More specifically, these are the verbs: "I am afraid" $(p=.000$, with a mean of 3.14 and 1.95 respectively), "I am careful" ( $p=.000$, with a mean of 4.39 and 3.41 respectively ), "I am worried" ( $\mathrm{p}=.000, \mathrm{M}=3.94$ and $\mathrm{M}=2.68$ respectively), "I look" ( $\mathrm{p}=.005, \mathrm{M}=3.33$ and 2.73 respectively), "I groom myself" ( $p=.003, M=2.88$ and 2.27 respectively), "I eat" ( $p=.003, M=3.71$ and 3.18 respectively) and finally "I read" ( $p=.001$, with a mean of 4.04 and 3.36 respectively).

Table 7 shows the distribution of students' responses about the person or organization that they will call on in the future seeking for help about a serious problem of living, based on their degree of concern about covid19. The same table presents the results related to the statistical significance test of the mean differences.

\section{Table 7}

Distribution of students' responses about the person or organization that will be sought in the future seeking help to address a serious living problem, based on their degree of concern about covid-19. Statistical significance test of mean differences

\begin{tabular}{|l|c|c|c|c|}
\hline \multirow{2}{*}{ Persons - Organizations } & \multicolumn{2}{|c|}{$\begin{array}{c}\text { Degree of concern about } \\
\text { covid-19 }\end{array}$} & \multicolumn{2}{|c|}{$\begin{array}{c}\text { Statistical } \\
\text { Significance Test }\end{array}$} \\
\cline { 2 - 3 } & $\begin{array}{c}\text { Low } \\
(\%)\end{array}$ & $\begin{array}{c}\text { High } \\
(\%)\end{array}$ & & \\
\cline { 2 - 3 } & 23,8 & 10,2 & & \\
\hline To my circle of friends & 47,6 & 57,1 & & \\
\cline { 1 - 3 } To my family & 0,0 & 2,0 & \multirow{2}{*}{10,301} & \multirow{2}{*}{.067} \\
\cline { 1 - 3 } To my circle of powerful acquaintances & 4,8 & 0,0 & & \\
\hline To civil services & 19,0 & 24,5 & \\
\hline To my personal strengths & 4,8 & 6,1 & & \\
\hline Other & & & & \\
\hline
\end{tabular}


The statistical significance test of Table 7 shows that there is no statistically significant difference in the views of students who have a high degree of concern about covid-19 compared to those who have a low level of concern about their views regarding the person or organization that they will call on in the future seeking help to address a serious living problem $(p=.067)$.

\section{DISCUSSION AND CONCLUSIONS}

The findings of the study showed differences in the views of students between those who expressed a high degree of concern about covid-19 and those with a low degree of concern.

Participants with a high degree of concern justify their choice because of the "unknown", the unprecedented of the epidemic, "it is a new virus, unprecedented, with different symptoms...". Some describe the virus as an "invisible enemy, unpredictable and bloodthirsty whose next move is unknown." The high level of concern is also strongly linked to economic and social reasons, to the needs of young people for socialization "Our lives have been frozen, both economically and socially, which has several negative consequences, not only in the field of health!". Other students experience it as a reversal that cancels their dreams and life plans. "I'm afraid, because we just want to live our lives peacefully, have a family and have a house." The high degree of concern is also associated with personal experiences and some traces of empathy: "I'm worried, unfortunately a member of my family went through it, I do not know about the effects it may have on his health later" or even "I'm worried because our store is closed, many people will lose their jobs".

The students, on the other hand, with a low degree of concern admit "that there is a virus with serious symptoms ...", in this way they want to manipulate us without at the same time being able to react ". For some, it is the fault of the media that exaggerate the events "I think that the situation is presented by the media in a dramatic way and in general they present it as they want in order to scare us". They shift the problem to outside intentions, with doses of suspicion "I do not believe it does not exist, but they have been exaggerated by big interests. I think it is a simple virus that someone will get over in a mild way and someone seriously". Finally, some students say that they are not worried, because they follow all the rules of protection, consider themselves responsible and protect themselves and those around them. Few students with a low degree of concern show complete denial of the facts.

Regarding the way students are informed about covid-19, it seems that the preferred media / persons are television, internet, family and circle of friends. Doctors and pharmacists are the least preferred individuals by students in both groups of the sample. Some, in fact, devalue their role with comments such as "I just do not pay attention to them anymore, because they say a lot of inaccuracies".

It is expected that students with a high degree of concern comply with the proposed precautionary measures to a higher degree, while it is the same group that during the quarantine period "unfolded" some talent, with favorite activities music, fitness - sports, the new fashion of Tik Tok and "the talent of patience".

Of the 17 suggested verbs that characterize the condition of the subjects during the lockdown period, the most prevalent are: I am afraid, I watch, I worry, I search, I groom myself, I eat, I read. The verb that differentiates the two groups is the verb "I do not care", chosen mainly by the group with a low degree of concern. Denial of intensity, underestimation of risk, shifting the problem to bad intentions and an attempt of manipulation constitute popular mechanisms among students with a low degree of concern.

Finally, all students consider that, when dealing with serious problems, a reliable helper is the family and the circle of friends, while regarding inhibiting factors when addressing serious problems, all students highlight ideological bankruptcy, endemic corruption, lack of prevention and planning, as well as deficiencies in the education system and dysfunctional civil services. These are highlighted more by the group with a low level of concern about covid- 19 .

The students of the sample belong to i-Generation. These are people who went to school in the 21st century and lived in a world where the internet has always existed. They are the first generation to go to school with "smartphone in their hands". According to the American psychologist and demographic data analyst Twenge (2006; 2017), there are differences in the behavior and psychological state of adolescents between successive generations, with thematic, however, changes in the 21st century, i.e in the i-generation. The landmark is the extensive use of internet and smartphone on a large scale. With similar conclusions in other western countries, this generation includes people who stay primarily safe in their area and have internet communication. With a prolonged childhood, overprotected, pampered by the family and the wider environment, this generation, according to research, progresses to a mutated adolescence that is neither childhood nor adulthood and oscillates between the two. They seem to be obsessed with security - the safe place, they insist on their individuality though with empathy for others, they are frightened by financial uncertainty and suffer from social anxiety, while they are attracted by technological developments such as 
artificial intelligence and robotics (Higgs, 2019).

Due to the special conditions of the lockdown within which the present study was conducted, the relatively small number of the sample, the digital presence of the first year students and their online acquaintance with the University, the staff of the Department and the Institution and mainly due to the pandemic, the findings of the present research seem to converge with international studies for their generation to some extent. They are afraid and worried, they pay attention and comply with the proposed measures against covid, they are informed mainly by television, internet and the family, they are afraid of the unknown-the new and they are supported psychologically mainly by the family and the circle of friends, which is related to psychological resilience (Nikolaou et al., 2021). Moreover, they show empathy to a certain extent and they seek security, challenging the general climate of ideology or dysfunctional government services.

Obviously, the issue of covid-19, quarantine and digital communication have a strong share of responsibility in these findings. We think that it will be very interesting to conduct studies on the Greek data in this igeneration for the post-covid era, regarding what imprint may the pandemic and quarantine have left on the behavior and psychological state of young people on the one hand, and how they cope with additional problems in university life and beyond, by what mechanisms, with what maturity and what empathy, on the other hand.

\section{REFERENCE LIST}

Akbulut, M., Sahin, U. \& Esen, A-C. (2020). More than a virus: How COVID 19 infected education in Turkey? Journal of Social Science Education, Vol 19, pp 30-42.

Alghamdi, A. (2021). Impact of the COVID-19 pandemic on the social and educational aspects of Saudi university students' lives. PLOS ONE 16(4): e0250026. https://doi.org/10.1371/journal.pone.0250026

Chaturvedi, K., Vishwakarma, D. \& Singh, N. (2021). COVID-19 and its impact on education, social life and mental health of students: A survey, Children and Youth Services Review, Elsevier, vol. 121(C). Available from: https://ideas.repec.org/a/eee/cysrev/ v121y2021ics019074092032288x.html

Dhawan, S. (2020). Online learning: A panacea in the time of COVID-19 crises. Journal of Educational Technology, 49(1), 5-22. https://doi.org/10.1177/0047239520934018

Higgs, J. (2019). The future starts here: Adventures in the Twenty-First century. London: Weidenfeld \& Nicolson.

Josephs, I.E., \& Valsiner, J. (2007). Developmental science meets culture: Cultural development psychology in the making. European Journal of Developmental Science, 1(4), 47-64.

Martin, M., \& Furiv, U. (2020). Covid-19 shows the need to make learning more flexible, University World News, 28-2-2020. Available from: https://www.universityworldnews.com/post.php?story=20200324115802272

Nikolaou, E. Papavasileiou, V., Andreadakis, N., Xanthis, A., Xanthacou, Y., \& Kaila, M. (2021). Promoting psychological resilience: preschool teachers' perspectives. International E-Journal of Advances in Social Sciences, 7 (19), 111-119

Saladino, V., Algeri, D. \& Auriemma, V. (2020) The Psychological and Social Impact of Covid-19: New Perspectives of Well-Being. Front. Psychol. 11:577684. doi: 10.3389/fpsyg.2020.577684

Tasis, Th. (2017). Policies of Bios II: Self-care in iconic society. Athens: Harmos (in Greek)

Twenge, J.M. (2006). Generation Me: Why Today's Young Americans are more confident, assertive, entitledand more miserable than before. Atria Paperback.

Twenge, J.M. (2017). iGen: Why today's super-connected kids are growing up less rebellious, more tolerant, less happy-and completely unprepared for adulthood. Atria Books.

Xanthacou, Y. (2011). Creativity and innovation in school and society. Athens: Diadrassi (in Greek)

Xanthacou, Y. \& Kaila, M. (2011). Creative Problem Solving. New York: Nova Science Publishers, inc

Xanthacou, Y., Kaila, M. \& Papavasileiou, V. (2018). "Imagination dead imagine" because you can trap birds with birdlime, but you cannot capture their song". New York: Nova Science Publishers. 